University of Nebraska - Lincoln

DigitalCommons@University of Nebraska - Lincoln

\title{
Comparative mapping of bovine chromosome 27 with human chromosome 8 near a dairy form QTL in cattle
}

\author{
E. E. Connor \\ USDA-ARS
}

M. S. Ashwell

North Carolina State University at Raleigh

R. Schnabel

University of Missouri-Columbia

J. L. Williams

Roslin Institute (Edinburgh)

Follow this and additional works at: https://digitalcommons.unl.edu/usdaarsfacpub

Part of the Agricultural Science Commons

Connor, E. E.; Ashwell, M. S.; Schnabel, R.; and Williams, J. L., "Comparative mapping of bovine chromosome 27 with human chromosome 8 near a dairy form QTL in cattle" (2006). Publications from USDA-ARS / UNL Faculty. 698.

https://digitalcommons.unl.edu/usdaarsfacpub/698

This Article is brought to you for free and open access by the U.S. Department of Agriculture: Agricultural Research Service, Lincoln, Nebraska at DigitalCommons@University of Nebraska - Lincoln. It has been accepted for inclusion in Publications from USDA-ARS / UNL Faculty by an authorized administrator of DigitalCommons@University of Nebraska - Lincoln. 


\title{
Comparative mapping of bovine chromosome 27 with human chromosome 8 near a dairy form QTL in cattle
}

\author{
E.E. Connor, ${ }^{a}$ M.S. Ashwell, ${ }^{a, b}$ R. Schnabel, ${ }^{c}$ J.L. Williams ${ }^{d}$ \\ ${ }^{a}$ Beltsville Agricultural Research Center, ARS, USDA, Beltsville, MD; \\ ${ }^{\mathrm{b}}$ North Carolina State University, Department of Animal Science, Raleigh, NC; \\ ${ }^{c}$ University of Missouri-Columbia, Animal Sciences Unit, Columbia, MO (USA); \\ d Roslin Institute (Edinburgh), Roslin, Midlothian, Scotland (UK)
}

Manuscript received 30 December 2004; accepted in revised form for publication by T. Haaf, 29 March 2005.

\begin{abstract}
In the absence of a complete and annotated bovine genome sequence, detailed human-bovine comparative maps are one of the most effective tools for identification of positional candidate genes contributing to quantitative trait loci (QTL) in cattle. In the present study, eight genes from human chromosome 8 were selected for mapping in cattle to improve breakpoint resolution and confirm gene order on the comparative map near the $40 \mathrm{cM}$ region of the BTA27 linkage map where a QTL affecting dairy form had previously been identified. The resulting map identified $A D R B 3$ as a positional
\end{abstract}

candidate gene for the QTL contributing to the dairy form trait based on its estimated position between 40 and $45 \mathrm{cM}$ on the linkage map. It is also a functional candidate gene due to its role in fat metabolism, and polymorphisms in the $A D R B 3$ gene associated with obesity and metabolic disease in humans, as well as, carcass fat in sheep. Further studies are underway to investigate the existence of polymorphisms in the bovine $A D R B 3$ gene and their association with traits related to fat deposition in cattle.

Copyright $\odot 2006$ S. Karger AG, Basel
Body condition may contribute to a dairy cow's susceptibility to a wide variety of diseases, fertility and health problems (Hansen et al., 2002; Lassen et al., 2003), as well as reproductive disorders (Rogers et al., 1999; Starbuck et al., 2004). The genetic correlation between body condition score and dairy form is -0.73 (Dechow et al., 2003). Quantitative trait loci

The nucleotide sequence data reported in this study were submitted to GenBank and assigned the accession numbers BV209032-BV209035. Radiation hybrid mapping was supported by the European Commission (Project QLRI-CT-200202744). Mention of trade names or commercial products in this article is solely for the purpose of providing specific information and in no way implies recommendation or endorsement by the U.S. Department of Agriculture.

Request reprints from Erin E. Connor

Beltsville Agricultural Research Center, ARS, USDA

10300 Baltimore Ave., Beltsville, MD 20705 (USA)

telephone: 301-504-6104; fax: 301-504-8414

e-mail: econnor@anri.barc.usda.gov
(QTL) associated with dairy form were identified by our laboratory within two regions of bovine chromosome 27 (BTA27) in two Holstein families (Ashwell et al., 2001; Van Tassell et al., 2004). Interval analysis indicated a likely QTL position at $40 \mathrm{cM}(95 \%$ confidence interval $27-52 \mathrm{cM})$ containing possibly one or two QTL and the second QTL located near the telomere. Thus the identification of genes contributing to variation in this trait could enhance our ability to modulate body condition and improve animal health and fertility through genetic selection for the most desirable alleles.

Due to the lack of information on the genes present in the regions of BTA27, we must rely on human-bovine comparative chromosome maps to identify positional candidate genes contributing to these QTL. Previous studies indicated that human chromosome 8 (HSA8) or HSA4 may contain regions of conserved synteny near the dairy form QTL located at $\sim 40 \mathrm{cM}$ on the BTA27 linkage map (Sonstegard et al., 2000; Connor et al., 2004). The purpose of the present study was to map genes positioned on human chromosomes which putatively shared con- 
Table 1. Summary of primer sequences, product sizes, annealing temperatures and GenBank accession numbers of source sequences used for PCR amplification of targeted bovine genomic regions

\begin{tabular}{|c|c|c|c|c|c|}
\hline Gene/BAC clone & Primer sequence & Product length (bp) & $\begin{array}{l}\text { Annealing } \\
\text { temperature }\left({ }^{\circ} \mathrm{C}\right)\end{array}$ & $\begin{array}{l}\text { Accession no./ } \\
\text { TIGR TC no. }\end{array}$ & $\begin{array}{l}\text { Putative } \\
\text { location }\end{array}$ \\
\hline Gene: $A D R B 3$ & $\begin{array}{l}\text { 5'-GGAGACCCTTTCCCTCATTC-3' } \\
\text { 5'-CAGGAGCGGAAGATAGAACG-3, }\end{array}$ & 700 & 58.5 & NM_174232 & exon 1 \\
\hline$B R F 2$ & $\begin{array}{l}\text { 5'-TGCTAACTGGCCTGACACAG-3' } \\
\text { 5'-ACCAAGGGATGGGACTCTCT-3' }\end{array}$ & 157 & 56.0 & TC243503 & exon 4 \\
\hline$C L U$ & $\begin{array}{l}\text { 5'-GACGCCCTGAATGACACC-3' } \\
\text { 5'-GATCCGCTTCTGCACACC-3' }\end{array}$ & 152 & 62.0 & NM_173902 & exon 4 \\
\hline EIF4EBPI & $\begin{array}{l}\text { 5'-CTAGCCCTACAGGCGATGAG-3' } \\
\text { 5'-CAAGATGGTCGCTTGCATAA-3' }\end{array}$ & $\sim 3000$ & 56.0 & TC205737 & intron 2 \\
\hline FUT10 & $\begin{array}{l}\text { 5'-CCACCTCCATCCGTTCTTTA-3', } \\
\text { 5'-GGCTTTGGTCCTGTGATGAT-3' }\end{array}$ & 193 & 56.0 & NM_182987 & exon 2 \\
\hline LEPROTL1 & $\begin{array}{l}\text { 5'-TGGCCTCCCTATCGTATTTG-3' } \\
\text { 5'-GGCCGAGAAATGACAAGAAG-3' }\end{array}$ & $\sim 1300$ & 58.5 & TC247955 & intron 3 \\
\hline MFHAS1 & $\begin{array}{l}\text { 5'-TTCTACGGCTGTGGGATTTC-3', } \\
\text { 5'-CCTCCCTGCCTCATCTACAG-3' }\end{array}$ & 173 & 58.5 & TC175989 & exon 4 \\
\hline MSRA & $\begin{array}{l}\text { 5'-CACCAGCAGTACCTGAGCAA-3' } \\
\text { 5'-CAGCTTGGTTCCCTGAAGTC-3' }\end{array}$ & 400 & 58.5 & NM_174114 & exon 11 \\
\hline BAC clone: $303 \mathrm{C} 7$ & $\begin{array}{l}\text { 5'-TTTTGTCTGCACTCCCTGTG-3', } \\
\text { 5'-GCAGGACTTAAGTGCCCAAA-3, }\end{array}$ & 538 & 55.0 & CC477059 & \\
\hline $393 \mathrm{M} 23$ & $\begin{array}{l}\text { 5'-GTCTAGCGGGGTCACAAAGA-3' } \\
\text { 5'-GGCTGAGCACTGTGTTTGAA-3' }\end{array}$ & 551 & 55.0 & CC592294 & \\
\hline 435D11 & $\begin{array}{l}\text { 5'-AGCCACTCGACGTGGTTTAC-3' } \\
\text { 5'-CATTTTCAGTGGTGGCCTTT-3' }\end{array}$ & 181 & 55.0 & CC550612 & \\
\hline $443 \mathrm{~K} 13$ & $\begin{array}{l}\text { 5'-AGGGATATGCATGAGGTTGG-3' } \\
\text { 5'-CCCTGGTCTCTCTCACACCT-3' }\end{array}$ & 236 & 55.0 & CC568501 & \\
\hline
\end{tabular}

GenBank accession number or TIGR Bos taurus Gene Index tentative consensus sequence (TC) number (http://www.tigr.org/).

served synteny with BTA27 and improve the human-bovine comparative map, particularly near the $40 \mathrm{cM}$ region of the BTA27 linkage map, to identify positional candidate genes regulating dairy form.

\section{Materials and methods}

Gene selection for mapping

Six genes (CLU, LEPROTL1, FUT10, ADRB3, BRF2 and EIF4EBP1) from the 27-39 Mb region of HSA8 and two genes (MFHAS1 and MSRA) from the $\sim 5-10 \mathrm{Mb}$ region of HSA8 were selected for mapping on the bovine genome. These genes were selected based on predicted conservation of synteny between this region of HSA8 and BTA27 and available bovine nucleotide sequence information. In addition, four CHORI-240 BAC clones (303C7, 393M23, 443K13 and 435D11) sharing high sequence similarity to HSA8 sequence in the 33-38 Mb region were selected for RH mapping.

Overgo oligo hybridization of CHORI-240 bovine BAC library filter sets (BACPAC Resources, Oakland, CA) was performed according to the methods of John McPherson (http://www.tree.caltech.edu/protocols/overgo. html) using the oligos ovBMS689F (5'-CCCTCTTCAGCTTGCCTCCCTTTC-3') and ovBMS689R (5'-GAGAAGTAGGATCAGGGAAAGGGA-3') and ovCSSM036F (5'-TCAACCACACGTCTCTGTCTTTGG-3') and ovCSSM036R (5'-GGCTTCCAAAGATCGTCCAAAGAC-3'). These overgo probes were designed to hybridize to unique regions flanking bovine microsatellite markers BMS689 (accession no. G18941) and CSSM036 (accession no. U03827), respectively, near our previously identified QTL peak for dairy form (Van Tassell et al., 2004). The BAC contigs containing positive clones identified by the hybridization were identified using iCE v3.4 (http:// ice.bcgsc.ca/). BAC end sequences available in the NCBI GenBank database from clones comprising the contig were compared to the Human Genome Draft sequence (April 2003 assembly) using BLAT analysis (http://genome. ucsc.edu/cgi-bin/hgBlat). High scoring alignments (score $>250$ ) were identified in the $33-38 \mathrm{Mb}$ region of HSA8; thus genes from this region were targeted for RH mapping in cattle.

\section{Primer design}

Table 1 summarizes the primer sequences, annealing temperatures and sources of bovine sequence information used for PCR amplification of each gene target. Primers were designed using Primer3 software (http://frodo. wi.mit.edu/cgi-bin/primer3/primer3 www.cgi). Amplification of the targeted region was confirmed by agarose gel purification of PCR products (QIAquick Gel Extraction Kit, Qiagen Inc., Valencia, CA) and direct sequencing using a CEQ8000 automated DNA sequencer with Quickstart chemistry (Beckman Coulter, Fullerton, CA). Nucleotide sequences generated for EIF4EBPI and LEPROTL1 were submitted to the GenBank dbSTS database and assigned accession nos. BV209032-BV209035.

\section{RH mapping}

Physical mapping of each locus was performed using the Roslin-Cambridge 3000-rad bovine/hamster radiation hybrid panel (Invitrogen Corp., Carlsbad, CA) as previously described (Connor et al., 2004). Amplification by PCR was performed in a $12-\mu 1$ reaction volume using $50 \mathrm{ng}$ of bovine genomic DNA as template, $0.4 \mu \mathrm{M}$ of each primer and Platinum PCR Supermix (Invitrogen Corp.). RH maps were constructed using the Carthagene package (Schiex and Gaspin, 1997) as described by Williams et al. (2002).

\section{Results and discussion}

Results of RH mapping and two-point analyses are presented in Table 2. Figure 1 illustrates relative marker order on BTA27 based on microsatellite markers included in the previous genetic map (indicated as USDA 97), and physical map (indicated as Williams 2002), with markers typed on the 3000$\mathrm{rad}$ RH panel in the present study (indicated as RH 2004). The addition of our markers described here did not change the number of LOD 6 linkage groups compared to the Williams 2002 map, although marker order in the telomeric linkage 
Fig. 1. Genetic and physical maps of chromosome 27. USDA 97 = linkage map from Kappes et al. (1997), units in cM; RH 2004 = physical map based on analysis of markers from the present work, units in $\mathrm{cR}$; Williams 2002 = physical map from Williams et al. (2002), units in cR. Heavy vertical lines to right indicate LOD 6 linkage groups. Arrows indicate framework markers within local frameworks shown with brackets. Hatched bar (left side) indicates $95 \%$ confidence interval of the dairy form QTL. QTL peak is at approximately $40 \mathrm{cM}$. Boxes surrounding marker names on $\mathrm{RH}$ 2004 map indicate loci positioned in the present study.
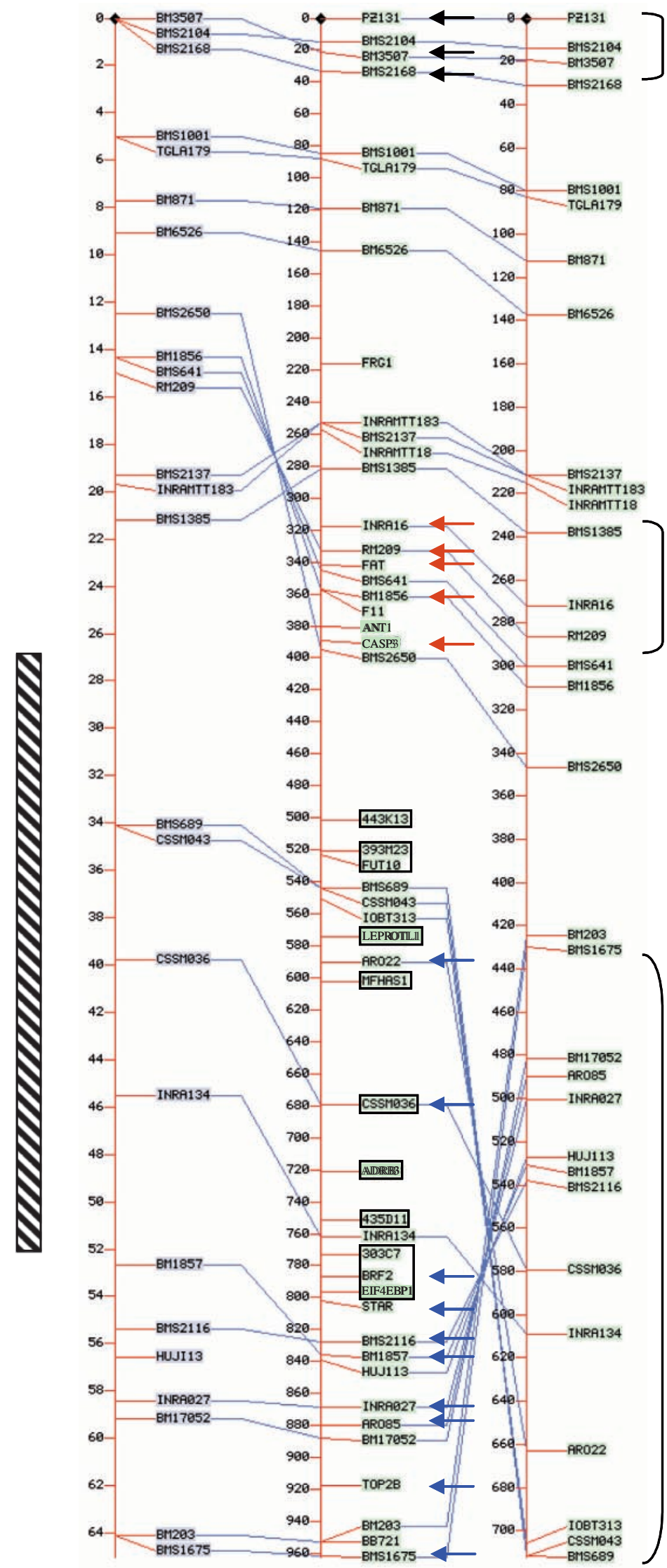

Framework 1

Framework 2

Framework 3

RH 2004 Williams 2002 
Table 2. Details of physical mapping of bovine gene- and BAC cloneassociated sequence tagged sites

\begin{tabular}{|c|c|c|c|c|c|}
\hline Locus$/$ clone $^{\mathrm{a}}$ & BTA & Closest locus & 2-point LOD & Distance (cR) & $\mathrm{HSA}\left(\times 10^{6} \mathrm{bp}\right)^{\mathrm{b}}$ \\
\hline$A D R B 3$ & 27 & INRA134 & 11.72 & 0.30 & $8(37.94)$ \\
\hline$B R F 2$ & 27 & INRA134 & 20.00 & 0.08 & $8(37.82)$ \\
\hline$C L U$ & 8 & IDVGA11 & 5.35 & 0.66 & $8(27.52)$ \\
\hline EIF4EBPI & 27 & STAR & 20.74 & 0.05 & $8(38.02)$ \\
\hline FUT10 & 27 & BMS689 & 13.21 & 0.19 & $8(33.39)$ \\
\hline LEPROTL1 & 27 & ARO22 & 15.92 & 0.16 & $8(30.02)$ \\
\hline MFHAS1 & 27 & $\mathrm{ARO} 22$ & 16.57 & 0.11 & $8(8.73)$ \\
\hline MSRA & 8 & KIAA1712 & 11.23 & 0.30 & $8(10.14)$ \\
\hline $303 \mathrm{C} 7$ & 27 & INRA134 & 18.76 & 0.10 & $8(38.16)$ \\
\hline $393 \mathrm{M} 23$ & 27 & IOBT313 & 13.56 & 0.20 & $8(33.99)$ \\
\hline 435D11 & 27 & INRA134 & 19.64 & 0.10 & $8(37.32)$ \\
\hline $443 \mathrm{~K} 13$ & 27 & IOBT313 & 9.88 & 0.36 & $8(35.14)$ \\
\hline \multicolumn{6}{|c|}{$\begin{array}{l}\text { a Clones are derived from the bovine BAC CHORI- } 240 \text { library } \\
\text { (http://www.chori.org/bacpac/bovine } 240 . \mathrm{htm} \text { ). Clone names indicate library plate, } \\
\text { row and column locations. } \\
\text { b Human Genome Working Draft (May } 2004 \text { assembly; http://genome.ucsc.edu/). } \\
\text { Number in parentheses is approximate number of bases from the p arm telomere of } \\
\text { the chromosome. }\end{array}$} \\
\hline
\end{tabular}

group was inverted. This inversion is consistent with marker order on the USDA 97 map and covers the majority of the QTL interval. In contrast, the orientation of the next linkage group towards the center of the chromosome (from markers $F R G 1$ to BMS2650) is consistent between the two physical maps but inverted relative to the linkage map. Placement of additional markers on the physical and genetic maps will aid in their future integration.

Two gene loci selected from HSA8 for mapping, MSRA (at $10.1 \mathrm{Mb}$ ) and MFHAS1 (at 8.7 Mb), were positioned on BTA8 and BTA27, respectively (Table 2). Mapping of MSRA is consistent with reports of Everts-van der Wind et al. (2004) and aids in the integration of the Roslin 3000-rad RH map and the ILTX-2004 second-generation 5000-rad RH map. Relative to the human genome sequence, the nearest gene marker to MFHAS1 positioned on both the human and bovine maps is DEFB1 (at $6.7 \mathrm{Mb}$ on HSA8), which maps near the center of BTA27. Thus mapping of MFHAS1 to the bovine genome extends the known region of conserved synteny on HSA8 with BTA27 by approximately $2.0 \mathrm{Mb}$, and narrows the location of the chromosomal breakpoint in the human-bovine comparative map to a $1.4-\mathrm{Mb}$ region of HSA8, between MSRA and MFHAS1.

Mapping of $C L U$ to BTA8 close to marker IDVGA11 (Table 2) is in agreement with previous reports (Band et al., 2000; Sonstegard et al., 2000; Goldammer et al., 2004) and corresponds to approximately $9 \mathrm{cM}$ on the bovine linkage map. This places $C L U$ in close proximity to MSRA in the bovine genome since $M S R A$ was close to $K I A A 1712$, a gene previously mapped to the same region of BTA8 (Connor et al., 2004). Our findings are consistent with the map of BTA8 from Everts-van der Wind et al. (2004; http://cagst.animal.uiuc.edu/RHmap2004/) and indicate the small region of BTA8 between $C L U$ and MSRA

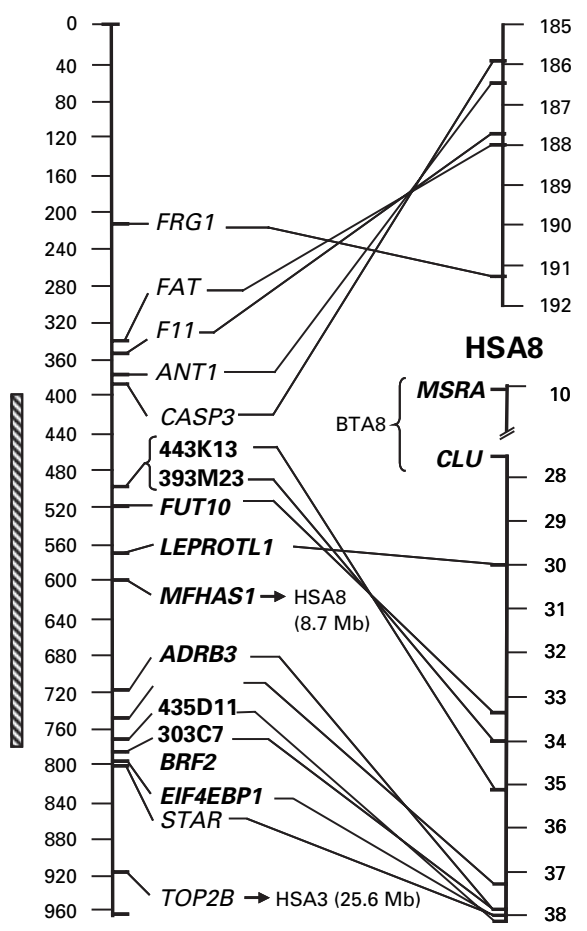

Fig. 2. Comparative alignment of BTA27 and HSA4 and 8 near previously identified QTL for dairy form on BTA27 (hatched bar to left indicates $95 \%$ confidence interval). Estimated positions for the bovine map are in $\mathrm{cR}$. Distances on HSA8 are in Mb from the $\mathrm{p}$ arm telomere based on Human Genome Working Draft (May 2004 assembly; http://genome.ucsc.edu/). Locus symbols indicated in bold were positioned in the present study. Previous assignments are from Connor et al. (2004) and were repositioned using Carthagene software.

corresponds to two separate regions of HSA8. Of interest, KIAA1712 is located on HSA4 at approximately $175.8 \mathrm{Mb}$. Thus the region of BTA8 between MSRA and KIAA1712 contains a breakpoint in the human-bovine comparative map corresponding to regions of HSA8 $($ at $\sim 10.1 \mathrm{Mb}$ ) and HSA4 (at $\sim 175.8 \mathrm{Mb}$ ), respectively.

The remaining loci, FUT10, LEPROTL1, MFHAS1, $A D R B 3, B R F 2, E I F 4 E B P 1$ and the STS markers 303C7, 393M23, 443K13 and 435D11 were mapped to BTA27 near the QTL region (Fig. 2). Mapping of these loci improves the marker density on the human-bovine comparative map primarily in the $30-38 \mathrm{Mb}$ region of HSA8. Mapping of EIF4EBP1 to BTA27 is consistent with findings of Goldammer et al. (2004), although placement of EIF4EPB1 relative to microsatellite marker CSSM036 is inverted compared to their map.

Based on multipoint analysis results, several rearrangements in gene order appear within small chromosomal segments of HSA8 compared to BTA27 within our QTL region (Fig. 2). Most significantly, MFHAS1 is positioned between LEPROTL1 and ADRB3 in the bovine genome, but near $M S R A$ in the $8.7 \mathrm{Mb}$ region of HSA8. This result suggests chro- 
mosomal regions on BTA27 between marker $443 \mathrm{~K} 13$ and STAR correspond to two separate regions of HSA8, one in the $8.7 \mathrm{Mb}$ region and one in the $30-40 \mathrm{Mb}$ region. Overall, our mapping results suggest genes positioned between $C A S P 3$ and $B R F 2$ are positional candidate genes contributing to the dairy form QTL located in the center of BTA27 (Fig. 2).

Dairy form is a subjective measure encompassing multiple characteristics primarily relating to the degree of fat deposition around the neck, shoulders, hips and topline of a dairy cow. A cow exhibiting a high dairy form score indicates the ability to mobilize energy into milk production rather than body reserves, hence the desirability of the trait. However, extreme dairy form can also be related to an increased susceptibility to metabolic diseases such as ketosis and reduced fertility (Rogers et al., 1999). Based on the factors contributing to the trait, the most obvious functional candidate within the chromosomal interval containing the QTL on BTA27 is ADRB3 (beta-3adrenergic receptor); a gene expressed primarily in adipose tissue that regulates energy metabolism.

In sheep, associations between allelic variation at the $A D R B 3$ locus and measures of carcass fat have been demonstrated (Forrest et al., 2003) and numerous studies examining a Trp64-to-Arg mutation in the human ADRB3 gene have found relationships between the mutation and metabolic disease and obesity (NCBI OMIM No. 109691). In cattle, there have been no reports of variation in the amino acid sequence of ADRB3 protein. Lastly, Revelli et al. (1997) developed ADRB3 knockout mice and found them to be more susceptible to obesity than wild-type mice. These observations suggest that $A D R B 3$ may mediate body fat deposition in dairy cattle and a variety of phenotypic traits including dairy form.
We performed a preliminary sequence analysis to identify polymorphisms near the $A D R B 3$ gene in the Holstein family segregating for the dairy form QTL. A single indel within the putative promoter of the $A D R B 3$ gene was identified for which the segregating sire was heterozygous. However, some sires that do not appear to be segregating for the QTL also exhibited the same heterozygous genotype for the indel, suggesting that this polymorphism is unlikely to be associated with the dairy form trait.

In conclusion, eight genes from the $0-40 \mathrm{Mb}$ region of HSA 8 and four bovine CHORI-240 BAC end sequence-associated STSs sharing high sequence similarity with the $33-38 \mathrm{Mb}$ region of HSA8 were selected for radiation hybrid mapping to the cattle genome. This information was used to improve the comparative map near the $40 \mathrm{cM}$ region of the BTA27 linkage map where a QTL for dairy form had been previously identified in a Holstein cattle population. The gene ADRB3, located at approximately $40-45 \mathrm{cM}$ on BTA27, was identified as a positional candidate gene contributing to the QTL based on the role of this gene in fat metabolism and its association with metabolic diseases and fat deposition in sheep, mice and humans. Additional work currently is underway to determine whether polymorphisms in the bovine $A D R B 3$ gene exist in dairy families segregating for the dairy form QTL and to study the associations between $A D R B 3$ and health and production traits such as dairy form, metabolic disease, and fat deposition in cattle. Further analysis and comparative mapping of HSA8 near the MFHAS1 locus is needed to determine whether additional functional candidate genes can be identified within the dairy form QTL interval on BTA27.

\section{References}

Ashwell MS, Van Tassell CP, Sonstegard TS: A genome scan to identify quantitative trait loci affecting economically important traits in a US Holstein population. J Dairy Sci 84:2535-2542 (2001).

Band MR, Larson JH, Rebeiz M, Green CA, Heyen DW, Donovan J, Windish R, Steining C, et al: An ordered comparative map of the cattle and human genomes. Genome Res 10:1359-1368 (2000).

Connor EE, Sonstegard TS, Ashwell MS, Bennett GL, Williams JL: An expanded comparative map of bovine chromosome 27 targeting dairy form QTL regions. Anim Genet 35:265-269 (2004).

Dechow CD, Rogers GW, Klei L, Lawlor TJ: Heritabilities and correlations among body condition score, dairy form and selected linear type traits. J Dairy Sci 86:2236-2242 (2003).

Everts-van der Wind A, Kata SR, Band MR, Rebeiz M, Larkin DM, Everts RE, Green CA, Liu L, et al: A 1463 gene cattle-human comparative map with anchor points defined by human genome sequence coordinates. Genome Res 14:1424-1437 (2004).

Forrest RH, Hickford JGH, Hogan A, Frampton C: Polymorphism at the ovine $\beta_{3}$-adrenergic receptor locus: associations with birth weight, growth rate, carcass composition and cold survival. Anim Genet 34:19-25 (2003)
Goldammer T, Kata SR, Brunner RM, Kuhn C, Weikard R, Womack JE, Schwerin M: High-resolution comparative mapping between human chromosomes 4 and 8 and bovine chromosome 27 provides genes and segments serving as positional candidates for udder health in cattle. Genomics 84 : 696-706 (2004).

Hansen M, Lund MS, Sorensen MK, Christensen LG: Genetic parameters of dairy character, protein yield, clinical mastitis, and other diseases in the Danish Holstein cattle. J Dairy Sci 85:445-452 (2002).

Kappes SM, Keele JW, Stone RT, McGraw RA, Sonstegard TS, Smith TP, Lopez-Corrales NL, Beattie CW: A second-generation linkage map of the bovine genome. Genome Res 7:235-249 (1997).

Lassen J, Hansen M, Sorensen MK, Aamand GP, Christensen LG, Madsen P: Genetic relationship between body condition score, dairy character, mastitis, and diseases other than mastitis in firstparity Danish Holstein cows. J Dairy Sci 86:37303735 (2003).

Revelli JP, Preitner F, Samec S, Muniesa P, Kuehne F, Boss O, Vassalli JD, Dulloo A, et al: Targeted gene disruption reveals a leptin-independent role for the mouse beta3-adrenoceptor in the regulation of body composition. J Clin Invest 100:1098-1106 (1997).
Rogers GW, Banos G, Sander-Nielsen U: Genetic correlations among protein yield, productive life, and type traits from the United States and diseases other than mastitis from Denmark and Sweden. J Dairy Sci 82:1331-1338 (1999).

Schiex T, Gaspin C: CARTHAGENE: constructing and joining maximum likelihood genetic maps. Proc Int Conf Intell Syst Mol Biol 5:258-267 (1997).

Sonstegard TS, Garrett WM, Ashwell MS, Bennett GL, Kappes SM, Van Tassell CP: Comparative map alignment of BTA27 and HSA4 and 8 to identify conserved segments of genome containing fat deposition QTL. Mamm Genome 11:682-688 (2000).

Starbuck MJ, Dailey RA, Inskeep EK: Factors affecting retention of early pregnancy in dairy cattle. Anim Reprod Sci 84:27-39 (2004).

Van Tassell CP, Sonstegard TS, Ashwell MS: Mapping quantitative trait loci affecting dairy conformation to chromosome 27 in two Holstein grandsire families. J Dairy Sci 87:450-457 (2004).

Williams JL, Eggen A, Ferretti L, Farr CJ, Gautier M, Amati G, Ball G, Caramorr T, et al: A bovine whole-genome radiation hybrid panel and outline map. Mamm Genome 13:469-474 (2002). 